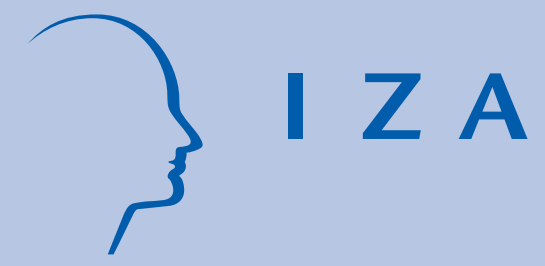

IZA Policy Paper No. 117

How Big is the Gig?

Assessing the Preliminary Evidence on the Effects of Digitalization on the Labor Market

Werner Eichhorst

Holger Hinte

Ulf Rinne

Verena Tobsch

October 2016 


\title{
How Big is the Gig? \\ Assessing the Preliminary Evidence on the Effects of Digitalization on the Labor Market
}

\author{
Werner Eichhorst \\ IZA
}

Holger Hinte

IZA

Ulf Rinne

IZA

\author{
Verena Tobsch \\ INES Berlin
}

Policy Paper No. 117

October 2016

IZA

P.O. Box 7240

53072 Bonn

Germany

Phone: +49-228-3894-0

Fax: +49-228-3894-180

E-mail: iza@iza.org

The IZA Policy Paper Series publishes work by IZA staff and network members with immediate relevance for policymakers. Any opinions and views on policy expressed are those of the author(s). IZA takes no institutional policy positions. The IZA research network is committed to the IZA Guiding Principles of Research Integrity.

The Institute for the Study of Labor (IZA) in Bonn is a local and virtual international research center and a place of communication between science, politics and business. IZA is an independent nonprofit organization supported by Deutsche Post Foundation.

The papers often represent preliminary work and are circulated to encourage discussion. Citation of such a paper should account for its provisional character. A revised version may be available directly from the corresponding author. 
IZA Policy Paper No. 117

October 2016

\begin{abstract}
How Big is the Gig? Assessing the Preliminary Evidence on the Effects of Digitalization on the Labor Market

This paper assesses the importance of digitalization in Germany and other developed countries with a particular attention to the potential or actual impact it may have on the labor market. Referring to available empirical evidence, we document the already developing transformation of occupations and forms of employment and the role of the platform economy, including the phenomenon of solo self-employment. We then derive current and future challenges for social protection and suggest some ideas to update social insurance in the face of these new challenges.
\end{abstract}

JEL Classification: J08, J24, O33, O38

Keywords: digitalization, robots, automation, future of work, industry 4.0, technical changes, sharing economy, platform economy, labor market, welfare state

Corresponding author:

Werner Eichhorst

IZA

P.O. Box 7240

53072 Bonn

Germany

E-mail: Eichhorst@iza.org 


\section{Introduction}

The digitalization of processes and work flows already influences our daily activities, including the nature of our communication, our social habits, but also, importantly, the functioning of our economies. How will these processes continue to develop in the foreseeable future?

There is strong speculation and discussion of many short- and long-term consequences of this process. The most prominent suggested outcomes are growing inequalities in the labor market, which can be seen in wage differentials both at the bottom and the top of the wage distribution, the dualization of the labor market via atypical or "precarious" employment, in the substitutability of human labor by robots and machines as well as in newly emerging forms of work in the so-called platform economy or gig economy.

The relevant literature mainly discusses four factors to explain increases in the (actual or perceived) uncertainty and inequality in labor markets. In addition to technical progress related to digitalization and automation, the others topics revolve around globalization, with a penchant for outsourcing and offshoring (Autor et al., 2016), flexibility and deregulation, characterized by a reduction in collective bargaining commitments and a liberalization of flexible employment forms (Eichhorst and Tobsch, 2015) and lastly, the emergence of numerous new internet platforms which create virtual marketplaces of private operators or groups and are acting as starting points for a variety of new services that fill gaps and stimulate demand (Eichhorst and Spermann, 2016).

Although our focus in what follows is primarily on the interplay of digitalization and employment forms, it should be noted that the above factors are each interdependently related, and their consequences can be mutually reinforcing. To shed some light on these developments, our paper outlines the dynamics of the digitalization process and uses empirical evidence of changes in employment over the course of the last two decades. In this context, we put particular emphasis on the role of the new platform economy and the associated challenges for existing systems of social protection.

\section{Possible Effects of Digitalization}

The digitalization of labor markets can be understood as a far-reaching process, which includes the penetration of value-added chains and productive processes - including in the service sector - by mainly internet-based technologies. Entire fields of work are being broken up into their constituent parts, automated and connected flexibly to each other. Local and global production chains are becoming more compatible with each other and therefore organized 
more efficiently. Routines can be put in the hands of intelligent machines and then optimized. At other points, digitalization creates new demanding tasks such as process control, coordination and creative design.

Although it is often assumed that the rapid digitalization of work will result in significant structural changes in employment opportunities (Brynjolfsson and McAfee, 2011), it would be advisable to be careful in assessing the speed of significant changes in the working world (Eichhorst et al., 2015). For example, about 20 years ago, the prediction of the rapid domination of the digital world was so popular that the "end of work" was sometimes spoken of (Rifkin, 1995). Obviously, though, this was not what happened in reality.

Earlier developments in the area of information and communication technology (ICT) are already very important in our daily social and professional lives, which can lead us to expect more substantial changes. A much acclaimed study predicts that, for example, about $47 \%$ of all employment in the United States will be under the threat of replacement by machines, robots or computer programs, at least in the medium term (i.e., in the next 10 to 20 years; Frey and Osborne, 2013). Other studies, however, suggest that neither technological progress in general nor digitalization in particular will broadly replace human labor. Rather, as in other eras, the outdated forms of employment that are no longer useful will be replaced by new forms better suited for the level of organizational and technological development (Eichhorst et al., 2013; Eichhorst and Buhlmann, 2015; Rinne and Zimmermann, 2016).

Trends in the labor market which have been influential in the recent past will most likely continue to accelerate with digitalization. This mainly means flexibility in the form of individually tailored temporary work and service contracts, freelance work, and multiple jobs. Throughout the course of digitalization, newly created jobs may only under certain conditions be conceived of as classic standard employment relationships with long-term employment prospects, collective contractual classifications and full social security. By using new technologies, companies will more easily than ever be put in the position of externally purchasing, or contracting, human capital when necessary, even in the short-term. In general, firms will increasingly organize in categories of temporary project work in temporarily active networks and concentrate their core workforce into a desired minimum in the segments where there is no shortage of skilled workers.

The breakdown of tasks and activity profiles made possible by digitalization creates a clear incentive to build a highly flexible and competitive "platform economy" where suppliers offer their services in the context of a professionally organized internet portal. The mediation of such services offered now happens online and via smartphone apps and can thus, at any time, be almost completely free of barriers. Currently existing platforms such as Uber, an 
intermediary for driving services, or, for example, TaskRabbit or Helpling, both intermediaries for varieties of (local) services and craft activities, show how fast and successfully such business models can take off.

But the platform economy is by no means limited to simple services. High quality consulting activities and work modules from highly specialized experts are also possibilities. Therefore, it is no fait accompli that the digital world of tomorrow will see an increase in "wage dumping" and that companies will only be willing to offer good work for low wages.

Although the reorganization of work cannot be completely predicted in all facets, it will have a significant impact on production factors, occupations and employment forms. This will result in new risks for individual labor market segments but, at the same time, provide a wide range of opportunities and potentially, in the best case scenario, even overcompensate for lost jobs. This will raise new questions as to what extent these presumed maximum welfare gains will be unequally distributed without political measures and to what extent individual groups will be exposed to a higher risk of suffering from an increasing polarization of the labor market.

Obviously, this entire process will also have direct consequences on the range and capacity of collective agreements (Eichhorst et al., 2015). Furthermore, it is clear that questions of social security will be thought about and framed in an entirely new way. It is not unlikely that, at the "end" of digitalization, a new "social security system 4.0" will have been created which might exhibit elementary characteristics of a universal social insurance system. It may thus include all forms of work, from self-employment and civil service to platform entrepreneurs working for themselves. This step appears clearer as the boundaries between the forms of employment become increasingly blurry. For many workers, the traditional classifications of "dependent employee" or "self-employed" no longer quite fit. Finally, systematic employee capital participation may be on the agenda more urgently than ever before - or, in other words, "who owns the robots rules the world" (Freeman, 2015). Likewise, though, new forms of organization will have to develop with respect to this as well. One might argue, for example, that employees in and around the company should also profit from the use of robots by means of innovative employee ownership models.

\section{The Preliminary Evidence}

What are the effects of digitalization that can already be observed today? And what other consequences are beginning to emerge? On the basis of current data and available research results, the following evidence provides answers to these questions. What it shows is that, in general, the digitalized world of work is no utopia, rather it has entered into daily life in more and more productive and professional fields over the years. In this respect, digitalization 
should be understood as a long-term evolutionary process rather than a sudden and disruptive revolution. The effects can nevertheless be empirically proven today, although these are often (at least so far) far less dramatic than is generally assumed.

\subsection{Transformation of Occupations and Job Profiles}

Previous research results on the impact of the developments in ICT already show specific changes in traditional occupations and job profiles. Formal qualifications do not necessarily appear to be the decisive criterion for a "future-proof" career. Seen globally, the increasing automation of work processes tends to polarize labor markets and shift employees out of the middle level of qualifications (Autor et al., 1998; Acemoglu and Autor, 2011).

It is also clear that the progressive integration of production processes and communication technologies will be followed by further significant restructuring in the context of "Industry 4.0" (Graetz and Michaels, 2015). The main occupations that are threatened by future rationalization measures are those that in particular demand high levels of precision and routine, in other words, where machines are superior to humans (Goos et al., 2014). The most future-proof areas of employment, however, will probably require high levels of creativity, social intelligence and entrepreneurial thinking to address bigger challenges.

Translating the frequently cited study by Frey and Osborne (2013) into the German context provides, at least superficially, similar results for the automation potential of jobs as in the United States (Bonin et al., 2015). An analogous approach on the basis of expert estimates predicts that the portion of jobs under threat by machines, robots and computer programs in the middle-term is, at $42 \%$, only slightly less than in the US. An alternative, activity-based approach, however, paints a less dramatic picture: According to this approach, only $12 \%$ of jobs in Germany have a relatively high risk of automation (and 9\% of jobs in the United States; Bonin et al., 2015). ${ }^{1}$ Dengler and Matthes (2015) arrive at similar results, with $15 \%$ of formal employees working in occupations where their work could to a great extent be done by a computer. Although the dimension of these smaller percentages should not be downplayed, a certain amount of caution in the assessment of technical automation potential seems appropriate. The negative effects on the labor market have often been greatly overestimated. The changes in the quantitative importance of occupations in Germany undoubtedly follow a long-term trend (Eichhorst and Buhlmann, 2015; Eichhorst et al., 2015). Figure 1 shows that

\footnotetext{
${ }^{1}$ Similar results came from an analysis of 21 OECD countries (Arntz et al., 2016). According to that analysis, an average of (only) $9 \%$ of jobs in these countries can be automated using an activity-based approach. However, there are relatively large differences between the individual countries. Germany and Austria top the list with an automation risk of $12 \%$, while this value was only about half as high for Korea, Estonia and Finland.
} 
the growth of employment in the period from 1996 to 2011 was concentrated in comparatively few occupational groups. The following occupational groups had a relatively strong growth rate of more than 20\%: personal and security service workers (group 51 in figure 1), sales and services elementary occupations (91), life science and health associate professionals (32), non-scientific teaching associate professionals (33), other professionals (24), other associate professionals (medium skill level) (34), corporate managers (12), physical, mathematical and engineering science professionals (21) as well as life science and health professionals (22). Conversely, the following occupational groups had a comparatively strong negative growth rate of $10 \%$ and more during the same observation period: agricultural, fishery and related laborers (92), skilled agricultural, forestry and fishery workers (61), diverse craft and related trades workers $(71,73,74)$, stationary plant and related operators (81) as well as legislators and senior officials (11).

On the one hand, these figures document the ongoing structural change from agricultural and craft occupations to occupations in the tertiary sector. Germany's transformation into a service economy continued dynamically in the late 1990s and early 2000s. On the other hand, it is clear that, at the same time, occupational groups with specific requirements, mainly in the tertiary sector, became substantially more important. As already mentioned, the requirements for these types of jobs include creativity (e.g., scientists), social intelligence (e.g., teachers) and entrepreneurial thinking (e.g., corporate managers).

As Figure 2 illustrates, these developments indeed come with a tendency towards polarization of the German labor market, which tends to push employees out of the middle salary and qualification segment. However, this development has, so far, been less dramatic in Germany than in other European countries (Goos et al., 2014; Eurofound, 2015). Nevertheless, empirical evidence of the changes in employment between 1995 and 2010 for occupational groups at the top and the bottom of the gross wage distribution was more strongly positive, while occupational groups in the middle of the wage spectrum showed rather weak employment growth. Examples of segments at the extremities are the professional/scientific occupational groups (groups 21 and 22 in figure 2) with a high wage level and very high employment growth on the one hand, and the craft occupational groups (71 and 74) with medium wage levels and quite a sharp decline in employment during the observation period on the other hand. In contrast, agricultural, fishery and related laborers (92) also showed comparatively strong employment growth, although they are positioned at the lower end of the gross wage distribution.

In this respect, important findings and forecasts in the international literature are also reflected in German data - at least to a certain degree. It is clear that especially creative occupations, occupations in corporate management and consulting as well as health, social 
and educational occupations have seen high rates of employment growth in the last 20 years. This simultaneous, moderate polarization results in a labor market which is characterized by a decline in the importance of routine activities, particularly in the middle wage and skill levels. However, it should be noted that in Germany, to date, there has not been an overall decline in employment, nor in the total numbers or volume of work. ${ }^{2}$ Gainful employment is therefore not in decline, contrary to some predictions; rather, the extent of growth is remarkably strong. In particular, higher qualified and more complex activities are gaining in importance in terms of employment and show a positive trend for wages at the same time.

\subsection{Changes in Forms of Employment}

More than ever before, our world of work is a world in motion. It is becoming more complex, but also more flexible. This not only has an impact on occupations and job profiles, but also on forms of employment and work (Rinne and Zimmermann, 2016). The two defining characteristics of the working society of tomorrow include increasing project work and network-based cooperation. Therefore, models of flexible working times consisting of working time credits, working from home and variable time planning will be the standard rather than the exception. The increasing scarcity of skilled labor along with growing pressure from competition and innovation will cause further innovations in work arrangements. Flexibility in the organization of work times or in the choice of work location will also blur the lines between private life and working life, with both desirable effects, such as a better balance between professional and family life, and possible negative effects (e.g., Eichhorst et al., 2016).

As a result, the traditional model of "standard employment" in the sense of permanent fulltime employment will be supplemented by other forms of employment. However, as Figure 3 shows, and as far as Germany is concerned, this results less from an absolute decline in the share of standard employment. While it is true that this share has declined a total of 5 percentage points during the observation period (from $45 \%$ in 1992 to $40 \%$ in 2014), it has been fairly stable at $40 \%$ since the mid-1990s. The strong decline in the share of the inactive population is more remarkable at 8 percentage points (from 26\% in 1992 to 18\% in 2014). Furthermore, the simultaneous increase in the importance of other, "atypical" forms of employment such as part-time work, fixed-term activities, temporary work and marginal employment has been quite large. The proportion of the unemployed, however, has stayed relatively constant between $6 \%$ and $8 \%$ during the observation period.

\footnotetext{
${ }^{2}$ Since the reunification of Germany, the number of employed persons in Germany reached a new peak of more than 43 million persons in 2015 (Federal Statistical Office, 2016). The volume of work done by employees in Germany also rose last year to just about 50 billion working hours and has reached a level not seen since the beginning of the 1990s (IAB, 2015).
} 
Figure 4 highlights more specifically the growth of atypical employment in various occupational groups in the period from 1996 to 2011. As can be seen, an increase in these forms of employment occurred in nearly all occupational groups. There is, therefore, no clear link to wage or qualification levels, although the higher than average increase in simple qualified segments and the particularly high level of atypical employment in sales and administration (91: sales and services elementary occupations, 11: officials) are remarkable. In any case, these effects do not seem to be caused by digitalization.

But the data does show how great the diversity of forms of employment and flexibility patterns in individual occupations and sectors has become in Germany. Nevertheless, it is still the case that flexible or atypical forms of employment mainly occur in areas where workers are easily available or replaceable. This phenomenon has long been an integral part of our working world, and since this change already began over two decades ago and was strongly influenced by institutional reforms, digitalization can be pointed to as only playing a minor role in this area at best.

Conversely, the use of long-term employment by firms seems to depend heavily on the respective production model as well as on the need for and availability of workers with specific qualifications. As a result, the proportion of standard employment relationships has been remarkably stable since around the turn of the century. In addition to an increase in atypical employment, it is an impressive development that there has not been a decline in standard employment in the German labor market. But there is another and probably even more important factor that can be observed in Germany's labor market: A significant proportion of the working-age population has been activated with new offers characterized by high flexibility. As a result, the number of inactive persons has decreased dramatically in the last twenty years (Arnold et al., 2016).

\subsection{The Role of the Platform Economy}

There is a third element of change with possibly significant effects on employment. Several indicators point to a greater role for the so-called platform economy. The success of the company Uber exemplifies how suppliers and customers, occasional drivers and passengers, can be matched on a "virtual market," putting the taxi industry under considerable pressure (see Hall and Krueger, 2015, for the United States). The basic principle could also be easily transferred to many other industries, including those that require mainly technical and knowledge workers. Appropriate platforms for these industries already exist: e.g., job offers for copywriters, programmers and designers are individually tendered and then processed. Interested companies put out a call to a "crowd" of more or less professional suppliers via these platforms and thus acquire their services, for which they no longer need to reserve 
either human or physical capital resources in-house (see on the phenomenon of crowdsourcing, for example, Leimeister and Zogaj, 2013; Leimeister et al., 2016). Some suppliers of the corresponding services are happy to use this opportunity to offer their work in a format that corresponds to their needs and earn something on the side. Others submit to such rules without having much of a choice, e.g., only to keep themselves in the market. In any case, the rising demand of companies for crowd workers means that potentially more and more independent and individual suppliers offer their services via the digital route and therefore compete with traditional business models based on firms with dependent employees. At the same time, the price structure for these services is increasingly coming under pressure.

In fact, through this process, there is a transfer of risks from the employer to the employee, or, more precisely, to the mostly (formal) self-employed contractors (Eichhorst and Spermann, 2016). This is because platforms such as Uber do not consider themselves employers, only intermediaries. Workers for platform-based exchanges are therefore no longer "classic" employees, rather they are self-employed, with all the associated risks-like accidents or sickness-and costs, such as for pensions, unemployment or nursing care. This results in new challenges for the social security systems.

What is the extent of the platform economy in Germany and Europe today? Because the availability of suitable data on the actual development and reality on the labor market has a certain time lag and because some phenomena cannot be adequately portrayed, accurately answering this question can be challenging. Figure 5 represents an attempt to measure the extent of freelance work and self-employment. According to this, there was a dramatic rise in solo self-employment from the mid-90s until about the middle of the 2000 s, particularly for qualified persons, women and part-time workers. In contrast, the changes in the number and proportion of the self-employed was relatively unremarkable.

Moreover, many start-ups in the form of self-employment without employees founded between 2002 and 2005 can be explained by the promotion of the "Ich-AG" ("Me, Inc.") and the easing of handicrafts trade laws in 2004. In addition to the barely identifiable role of the platform economy in the last few years, the numbers observed also embody the effects of changes in the institutional and legal framework conditions. Conversely however, there has been a decline in the number of solo self-employed since 2012, including those who were not supported by the German Federal Employment Agency. Existing data so far does not show any evidence of a (massive) growth of the platform economy; therefore, this phenomenon can hardly be expected to have dramatic effects in the current situation. Even when looking at European data, solo self-employment (with or without agriculture) does not seem to be on the rise in general. Neither do we see an increase in the number of workers with a second job 
in German or European data (Figure 7). However, both findings might point to a measurement issue as online-based crowd-working may not be reported as a main or secondary activity by the respondents. Hence, most of the information on actual crowd working comes from relatively small and less representative surveys.

Studies on the income situation for the self-employed indicate a comparatively large spread in earnings and only a low level of ability or willingness to make contributions to retirement planning (Brenke 2013, 2015; Brenke and Beznoska, 2016). A similar development can be observed in employees who say they do occasional or regular secondary jobs when asked in representative surveys such as the SOEP. Since the early 2000s, according to our analysis of the SOEP, a stable percentage of $2.5 \%$ to $3.0 \%$ of employable people regularly or occasionally engage in secondary activities. These are more likely to be dependent employment relationships, i.e., mini-jobs, which have increased since being reformed in 2003.

At this point, the platform economy (as a form of the sharing economy) has only begun its development. All the signs indicate that its actual importance, not only in Germany, is still negligible. Even in the United States, which plays a leading role in this regard, the proportion of working people who offer their services through online platforms such as Uber or TaskRabbit is estimated at only $0.4 \%$ to $0.5 \%$ (Katz and Kruger, 2016; Farrell and Greig, 2016; Harris and Krueger, 2015). A UK online survey finds a share of $11 \%$ for actual crowd workers; yet, the representativeness of such small surveys remains an issue. At the same time, available data suggest that, in most cases, usually secondary jobs are done via these only platforms, with the resulting income supplementing other types of household income (see, for example, Huws and Joyce, 2016, for the UK), e.g., earnings from dependent or self-employed main activities or a partner's income. Hence, in general, online platform work is seen as an additional earning opportunity on top of "offline" activities (see, e.g., Katz and Krueger, 2016). Still, according to the UK survey (Huws and Joyce, 2016) and to a survey covering the US by Berg (2016), about one third of crowd workers rely on crowd work as a main source of income. Based on this information, this new labor market segment has the potential to develop dynamically and expand to cover a wider range of services, at least in some areas and occupations where labor is easily available. The task of social policy will then be to engage early enough with the associated emerging challenges, in particular armed with a framework creating a level playing field between different types of suppliers.

\section{Challenges for Social Policy}

Although currently no massive growth of solo self-employment can be observed, potential policy challenges have to be addressed to find timely answers. There are two central themes 
to consider. On one hand, many freelancers lack appropriate pension insurance, meaning that they cannot expect a living pension in the case of a longer period of self-employed work or if this is their main source of income. If crowd working is the main activity, the coverage and capacity to contribute to pension insurances and other types of social security is more limited than in the case of being protected under a dependent (or, in some cases, self-employed) main job. This is, for example, highlighted both by the German findings from Leimeister et al. (2016) and the US study by Berg (2016). They would then be dependent on tax-financed basic social security. In this light, solutions to organize adequate provision schemes appears to be necessary. On the other hand, there is the potential for competition between companies with regular employees-which make employer contributions to the social security system-and platforms-which formally use self-employed people and therefore push social insurance onto these persons because they do not see themselves as employers. Therefore, a possible expansion of formal self-employed work can, in principle, undermine the social security model.

A first approach in observing the dynamics of this situation is to trace the distinction between salaried and self-employed activities. The borders between these forms of employment are undoubtedly increasingly blurry. This implies that traditional classifications and schemes are no longer applicable. Marking a clear boundary between dependent employees and selfemployed workers is becoming more and more difficult. In the US as well as in Germany, there is a great deal of discussion about the sociopolitical implications of the distinctions between actual and "bogus" self-employed and salaried workers, and thus consequentially the role of employers. The platforms are in many ways acting as employers on which the service providers are economically dependent. That is why, for example, in the US, the introduction of a new (legal) category of "independent worker" is being discussed specifically to harmonize the social security system with the requirements of the platform economy and to bring it into the digital world of work (Harris and Krueger, 2015). Already some time ago, Austria introduced the construct of a "free service contract" to replace the classic work contracts with a form of employment based on hourly-wage payroll accounting, including full social security contributions. Specific difficulties arise, however, with privileges and benefits linked to working time or hourly wages (such as overtime rules and minimum wage provisions) because, in some cases, workers in the platform economy no longer work for an "employer."

A similar discussion is under way in Germany under the topic of work contracts and "bogus" self-employment. The stricter the requirements for "real" and legal self-employed work are, the more likely it is for formally self-employed people, who are actually economically dependent, to be reclassified as dependent employees for which employers have to pay social 
contributions. However, there is always the question of supervision and enforcement in each jurisdiction.

A second approach is the extension of the forms of employment or categories of workers that are included in social security. This applies in particular to social security for old age and disability, but also for unemployment. Slightly more than half of all self-employed in Germany have no pension in the form of payments into a pension program or life insurance (Brenke and Beznoska, 2016, p. 53). In Germany, according to present law and historical developments in law, only certain groups of "employee-like" self-employed individuals are legally required to pay into the statutory pension insurance scheme according to $\S 2$ of the German Code of Social Law, Book VI. This applies to teachers and educators, nurses and midwives, sea pilots and coastal shipping pilots, household workers, craftsmen as well as the self-employed with only one customer. In most of these groups, there is no compulsory insurance if they employ dependent employees. Artists and journalists have access to social security insurance for artists, and farmers have access to a separate model. Other groups of self-employed persons in established occupations, such as doctors, architects, tax advisors, notaries and lawyers, are insured in the context of professional insurance systems, while old-age savings are merely voluntary for many other groups of 'new' self-employed people.

Protection in the unemployment insurance system has so far been voluntary in principle. Since 2003, there has been the little-known possibility of extended voluntary insurance in the unemployment insurance system under the so-called "Versicherungspflichtverhältnis auf Antrag" (Compulsorily Insured Status on Request) (§ 28a of German Code of Social Law, Book III). This option is only available, however, if the person had pensionable, dependent employment for at least 12 months within the 24 months immediately prior to taking up selfemployed activity or the person obtained unemployment insurance benefits. If the insured self-employed person took unemployment benefit I more than twice, this extended insurance is not available, unless a new basis for compulsory insurance status has been acquired.

Against this background, it seems plausible to bring self-employed workers of all "types" into the social security system and not give them an "opt-out" option in the case of an appropriate and "living" private or professional pension. On the contrary, at least a minimum level of contributions to the social security system should be provided by this group, up to a contribution limit to be determined. The contributions of the self-employed workers themselves would then be supplemented by compulsory contributions from the customers or the intermediaries / platforms (as an equivalent to an employer). These could be paid directly by them or be claimed by the self-employed person when invoicing for their services. The model of social security for artists (Künstlersozialkasse) is an example in which the liability for contributions is on the user. In addition, a certain percentage of tax financing could be 
considered, as we see now in the cases of the statutory pension insurance and social security insurance for artists. There would, of course, also be tax revenue from entrepreneurial activities from platform-based activities.

Implementing a tax or social security contribution liability in the platform economy would be another challenge. Transactions on platforms when a job is done with a territorial reference to Germany, i.e., if the intermediaries, customers or contractors are located in Germany, could be taxed with a corresponding "social security contribution" comparable to a sales tax. Clearly then incentives to formal self-employed work would be reduced because the obligation to make social contributions would lead to higher prices or labor costs. This would be the price for universal engagement in the social welfare state and the prevention of "unfair" competition at the expense of the social insurance funds or the taxpayers.

The advantage of a more universal social security insurance system lies in the fact that the problem of the distinctions between self-employment, "bogus" self-employment and salaried employment, which are currently being discussed in Germany in the context of work contracts, will be substantially mitigated. A vision of the future is, therefore, "citizen insurance 4.0," which will include all employees equally and without privileges. Such a model of solidarity, which no one can opt-out of, will still face new arguments due to emerging employment trends and the resulting changes in insurance needs.

Moreover, the digitalization of the working world and the introduction of intelligent machines into the everyday work of increasingly more employment groups is reason enough to conceptualize models of employee capital participation, including in the sense of old-age pensions, and to make them more comprehensive than ever before. This need is underlined not least by the long phase of missing yields of classical forms being witnessed in investment and pension modules. Hence, promoting capital ownership and thereby income from holding shares could be a plausible response to this trend. However, policies would have to be designed carefully in order to effectively reach also those outside of larger firms that are more likely to be employee shareholders.

\section{Summary and Conclusions}

The widespread speculation about the rapid changes in our working world as a result of unprecedented technological innovations is an indication of the considerable uncertainty about the extent of the need for adjustments in the economy and society. For many of us, digitalization has become synonymous with uncontrollable technical developments in the working world, resulting in massive job losses and leading to severe social inequality, of which the most vulnerable individuals bear the burden. On the other hand, unrealistic expectations 
are formulated which assume that the past experiences of technical progress will continue unchanged in the future and, after a transition period of job losses and rationalization, new, creative jobs will be generated in great numbers and social prosperity can be ensured or even further expanded.

The empirical evidence in this article paints the picture of a labor market going through a profound transformation. As of today, despite a huge public debate, the scope of the platform economy still seems to be limited. In Germany, the number of solo self-employed has declined since 2012, and the proportion of those employed in the platform economy is as of yet very small, even in the United States. Besides that, there has not been any indication that digitalization will lead to mass unemployment. On the contrary, employment levels have been remarkably robust in Germany in the last few years when looking at the number of those employed as well as at the volume of work in hours. Despite measurement issues related to regular representative surveys, which might not be able to capture the full extent of crowd workers, society should continue to pay close attention to the potential changes triggered by digitalization: that is, enormous and dramatic developments are likely still ahead of us.

As we have seen, because of these changes, initially small start-ups can effectively put pressure on whole markets and industries, turning them on their heads by establishing new business models. The time has now come to identify new policy challenges presented by digitalization and to design appropriate measures. When transitioning into the digital world of work, it will undoubtedly be crucial to keep close attention on the ratio of winners and losers. For this reason, the expansion of employee capital participation formats will become an important policy design question. In addition, researchers and policy makers need to assess the extent to which the concept of social insurance, which is principally based on long-term dependent employment, should be systematically opened up to other forms of employment, and ultimately for all forms of employment. A contribution-based pension scheme for retirement as well as for occupational disability and unemployment regardless of formal employment status would close the gaps in insurance, ease changing forms of employment and reduce the competition over labor costs between dependent employees and those who are self-employed. Funding, therefore, will likely have to involve some form of contribution from customers and/or platform-based intermediaries involved in the transactions made. 


\section{References}

Acemoglu, Daron/David H. Autor (2011): Skills, Tasks and Technologies: Implications for Employment and Earnings. Handbook of Labor Economics, vol. 4, chap. 12, 1043-1171. Amsterdam.

Arnold, Michael/Anselm Mattes/Gert G. Wagner (2016): Normale Arbeitsverhältnisse sind weiterhin die Regel. DIW Wochenbericht 19/2016, 419-427.

Arntz, Melanie/Terry Gregory/Ulrich Zierahn (2016): The Risk of Automation for Jobs in OECD Countries: A Comparative Analysis. OECD Social, Employment and Migration Working Papers No. 189.

Autor, David H./Lawrence F. Katz/Alan B. Krueger (1998): Computing Inequality: Have Computers Changed The Labor Market? Quarterly Journal of Economics 113(4), 1169-1213.

Autor, David H./David Dorn/Gordon H. Hanson (2016): The China Shock: Learning from Labor Market Adjustment to Large Changes in Trade. NBER Working Paper No. 21906.

Berg, Janine (2016): Income security in the on-demand economy: Findings and policy lessons from a survey of crowdworkers, ILO CONDITIONS OF WORK AND EMPLOYMENT SERIES No. 74

BMWi (2015): Impulse für die Digitalisierung der deutschen Wirtschaft - Digitale Agenda des BMWi. Berlin: Bundesministerium für Wirtschaft und Energie (BMWi).

Bonin, Holger/Terry Gregory/Ulrich Zierahn (2015): Übertragung der Studie von Frey/Osborne (2013) auf Deutschland. ZEW-Kurzexpertise Nr. 57. Mannheim: Zentrum für Europäische Wirtschaftsforschung (ZEW).

Brenke, Karl (2013): Allein tätige Selbständige: starkes Beschäftigungswachstum, oft nur geringe Einkommen. DIW Wochenbericht 7/2013, 3-16.

Brenke, Karl (2015): Selbständige Beschäftigung geht zurück. DIW Wochenbericht 36/2015, 790-796.

Brenke, Karl/Martin Beznoska (2016): Solo-Selbständige in Deutschland - Strukturen und Erwerbsverläufe. Kurzexpertise für das BMAS. (http://www.bmas.de/DE/Service/Medien/ Publikationen/Forschungsberichte/Forschungsberichte-Arbeitsmarkt/fb-465-solo-selbstaendige.html; zuletzt aufgerufen am 9.6.2016).

Brynjolfsson, Erik/Andrew McAfee (2011): Race Against the Machine: How the Digital Revolution is Accelerating Innovation, Driving Productivity, and Irreversibly Transforming Employment and the Economy. Lexington.

Brynjolfsson, Erik/McAfee, Andrew (2014): The Second Machine Age: Wie die nächste digitale Revolution unser aller Leben verändern wird. Kulmbach.

Degryse, Christophe (2016): Digitalisation of the economy and its impact on labour markets, ETUI Working Paper 2016.02

Dengler, Katharina/Britta Matthes, Britta (2015): Folgen der Digitalisierung für die Arbeitswelt Substituierbarkeitspotenziale von Berufen in Deutschland. IAB-Forschungsbericht 11/2015.

Eichhorst, Werner/Florian Buhlmann (2015): Die Zukunft der Arbeit und der Wandel der Arbeitswelt, Wirtschaftspolitische Blätter 62(1), 131-148.

Eichhorst, Werner/Patrick Arni/Florian Buhlmann/Ingo E. Isphording/Verena Tobsch (2015): Wandel der Beschäftigung: Polarisierungstendenzen auf dem deutschen Arbeitsmarkt. IZA Research Report No. 68.

Eichhorst, Werner/Holger Hinte/Alexander Spermann/Klaus F. Zimmermann (2015): Die neue Beweglichkeit: Die Gewerkschaften in der digitalen Arbeitswelt. IZA Standpunkt Nr. 82.

Eichhorst, Werner/Michael Kendzia/Hilmar Schneider/Florian Buhlmann (2013): Neue Anforderungen durch den Wandel der Arbeitswelt: Kurzexpertise für die Enquete-Kommission „Wachstum, Wohlstand, Lebensqualität" des Deutschen Bundestages. IZA Research Report No. 51.

Eichhorst, Werner/Alexander Spermann (2016): Sharing Economy: Mehr Chancen als Risiken? Wirtschaftsdienst 96(6), S. 433-439. 
Eichhorst, Werner/Verena Tobsch (2015): Flexible Arbeitswelten: Eine Bestandsaufnahme. In: Werner Widuckel et al. (eds.): Arbeitskultur 2020. Wiesbaden.

Eichhorst, Werner/Verena Tobsch/Caroline Wehner (2016): Neue Qualität der Arbeit? Zur Entwicklung von Arbeitskulturen und Fehlzeiten. In: Bernhard Badura et al. (eds.): Fehlzeiten-Report 2016. Berlin. Berlin.

Eurofound (2015): Upgrading or polarisation? Long-term and global shifts in the employment structure: European Jobs Monitor 2015. Publications Office of the European Union, Luxembourg.

Farrell, Diana/Fiona Greig (2016): The Online Platform Economy: What is the growth trajectory? (https://www.jpmorganchase.com/corporate/institute/institute-insights.htm; zuletzt aufgerufen am 14.6.2016).

Federal Statistical Office (2016): Zahl der Erwerbstätigen stieg im Jahr 2015 auf 43 Millionen Personen. Pressemitteilung Nr. 001 vom 4.1.2016.

Freeman, Richard B. (2015): Who owns the robots rules the world. IZA World of Labor 2015:5.

Frey, Carl Benedikt/Michael A. Osborne (2013): The Future of Employment: How Susceptible are Jobs to Computerisation?, University of Oxford (http://www.oxfordmartin.ox.ac.uk/downloads/ academic/The_Future_of_Employment.pdf; zuletzt abgerufen am 3.6.2016).

Goos, Maarten/Alan Manning/Anna Salomons (2014): Explaining Job Polarization: Routine-Biased Technological Change and Offshoring. American Economic Review 104(8), 2509-2526.

Graetz, Georg/Guy Michaels (2015): Robots at Work. IZA Discussion Paper No. 8938.

Hall, Jonathan V./Alan B. Krueger (2015): An Analysis of the Labor Market for Uber's Driver-Partners in the United States. Working Papers No. 587, Princeton University, Industrial Relations Section.

Harris, Seth/Alan B. Krueger (2015): A Proposal for Modernizing Labor Laws for Twenty-First-Century Work: The "Independent Worker". The Hamilton Project, Discussion Paper 2015-10.

Hirsch-Kreinsen, Hartmut (2016): Arbeit und Technik bei Industrie 4.0. Aus Politik und Zeitgeschichte (APUZ) 66(18-19),10-17.

Huws, Ursula/Joyce, Simon (2016): Crowd working survey: Size of the UK's 'Gig Economy' revealed for the first time. University of Hertfordshire.

IAB (2015), Anhangtabellen zu IAB-Kurzbericht 4/2015, 19.2 .2015 (http://doku.iab.de/kurzber/ 2015/kb0415_Anhang.pdf; zuletzt aufgerufen am 6.6.2016).

Katz, Lawrence F./Alan B. Krueger (2016): The Rise and Nature of Alternative Work Arrangements in the United States, 1995-2015

(http://scholar.harvard.edu/files/lkatz/files/katz_krueger_cws_v3.pdf; zuletzt aufgerufen am 14.6.2016).

Leimeister, Jan M./Shkodran Zogaj (2013): Neue Arbeitsorganisation durch Crowdsourcing - Eine Literaturstudie. Hans Böckler Stiftung - Arbeit und Soziales, Arbeitspapier 287. Düsseldorf.

Leimeister, Jan M./Shkodran Zogaj/David Durward/Ulrich Bretschneider (2015): Neue Geschäftsfelder durch Crowdsourcing: Crowd-basierte Start-ups als Arbeitsmodell der Zukunft. In: Reiner Hoffmann/Claudia Bogedan (eds.) Arbeit der Zukunft - Möglichkeiten nutzen - Grenzen setzen. Frankfurt/M., 141-158.

Leimeister, Jan M./David Durward/Shkodran Zogaj (2016): Crowd Work in Deutschland - Eine empirische Studie zum Arbeitsumfeld auf Crowdsourcing-Plattformen. Düsseldorf: Hans Böckler Stiftung.

Rifkin, Jeremy (1995): Das Ende der Arbeit. Frankfurt, New York.

Rinne, Ulf/Klaus F. Zimmermann (2016): Die digitale Arbeitswelt von heute und morgen. Aus Politik und Zeitgeschichte (APuZ) 66(18-19), 3-9. 
Figure 1: Employment by Occupations (Change in \%, 1996-2011).

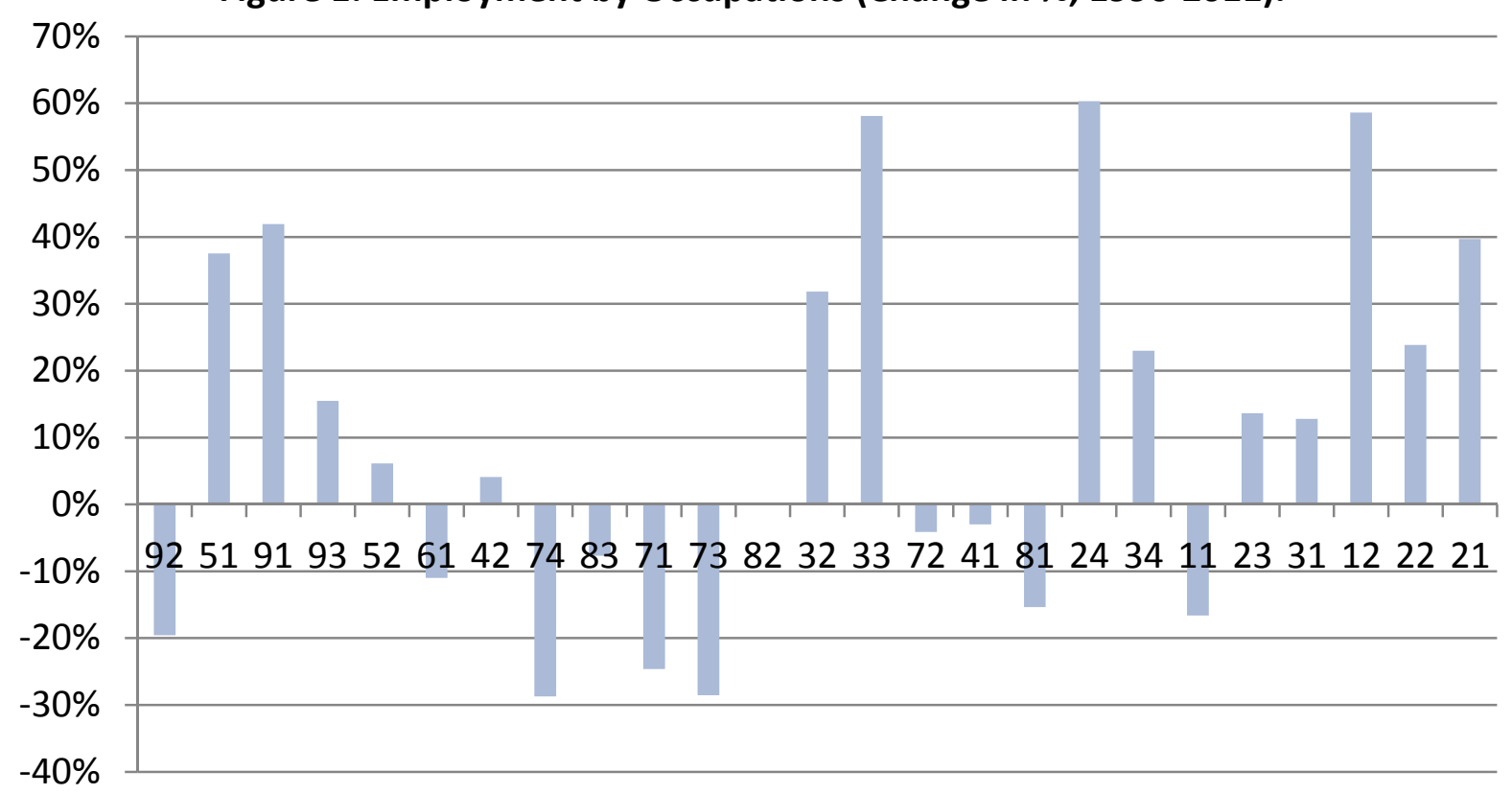

Source: Microcensus, our own calculations; occupational groups according to ISCO-88 (see table in appendix) sorted by median wages, 2010 from SIAB.

Figure 2: Gross wages in 1995 and employment development (1995=100) for individual occupational groups, full-time employees in Germany (1995-2010).

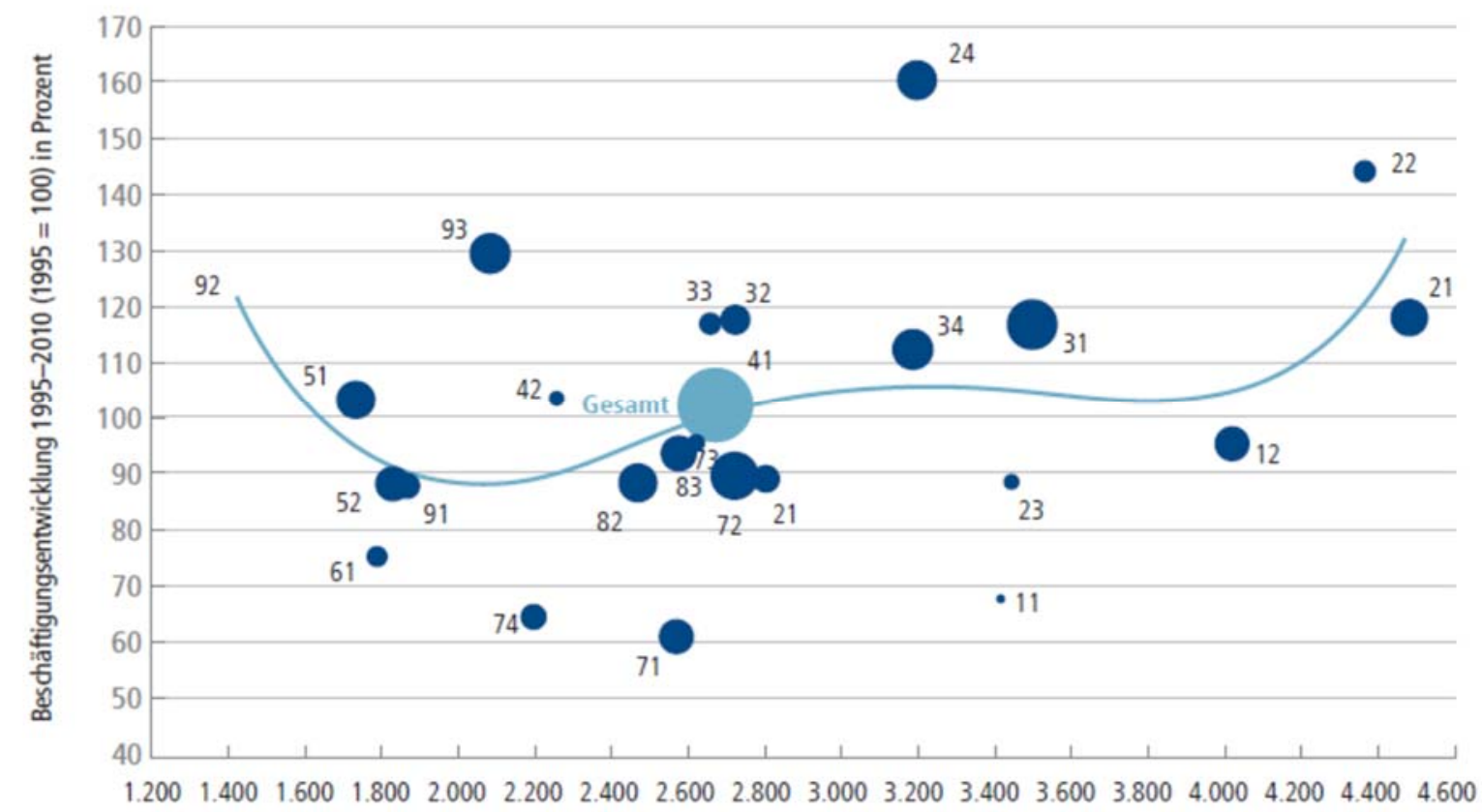

Source: SIAB, own calculations; occupational groups according to ISCO-88 (see table in appendix). 
Figure 3: Working-age population according to main activity status (1992-2014).

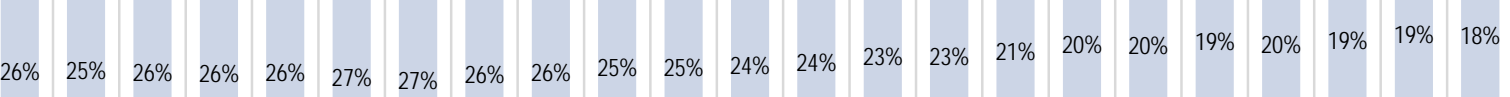

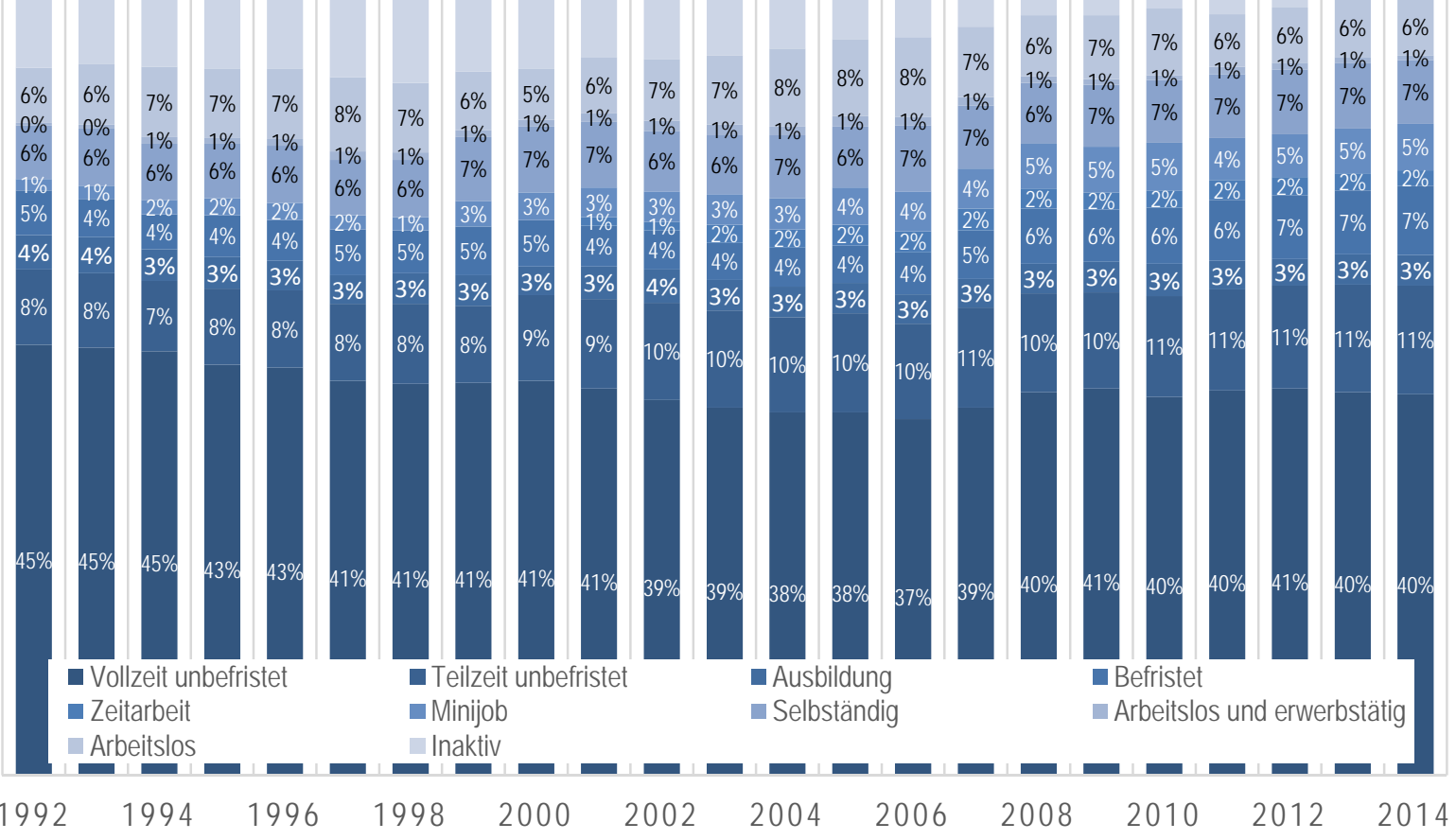

Source: Eichhorst et al. (2016) based on GSOEP 1992-2014 using cross-sectional weights.

Figure 4: Share of atypical work (marginal employment, temporary work, temporary agency work, self-employment; 1996-2011).

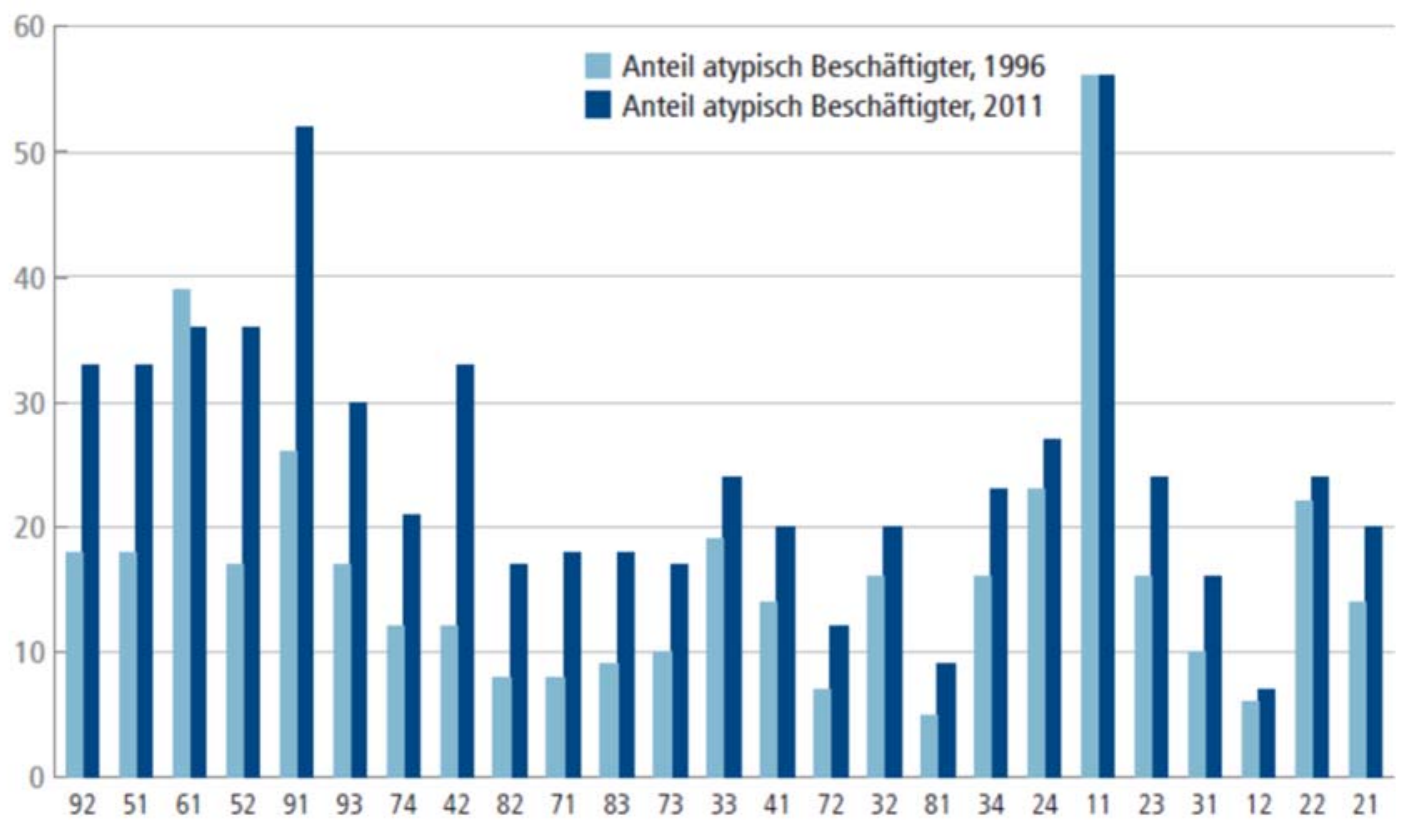

Source: Microcensus, own calculations; occupational groups according to ISCO-88 (see table in appendix) sorted by median wages, 2010 from SIAB. 
Figure 5: Development of the number of solo self-employed, self-employed with employees and the proportion of the self-employed to all employees (1991-2014).

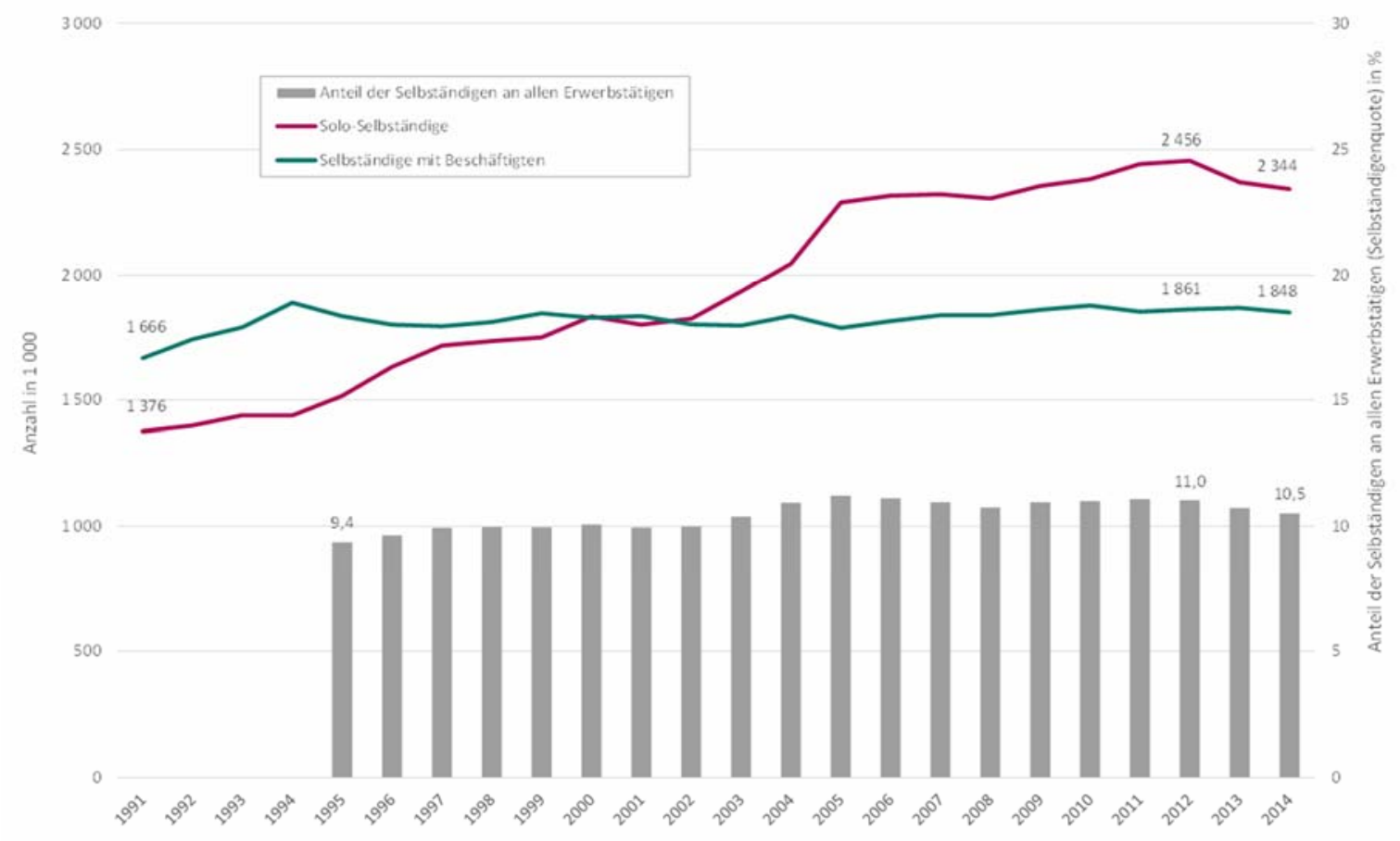

Source: Brenke/Beznoska (2016). Using Eurostat data.

Figure 6: Freelance employment outside agriculture in the EU, as \% of total employment

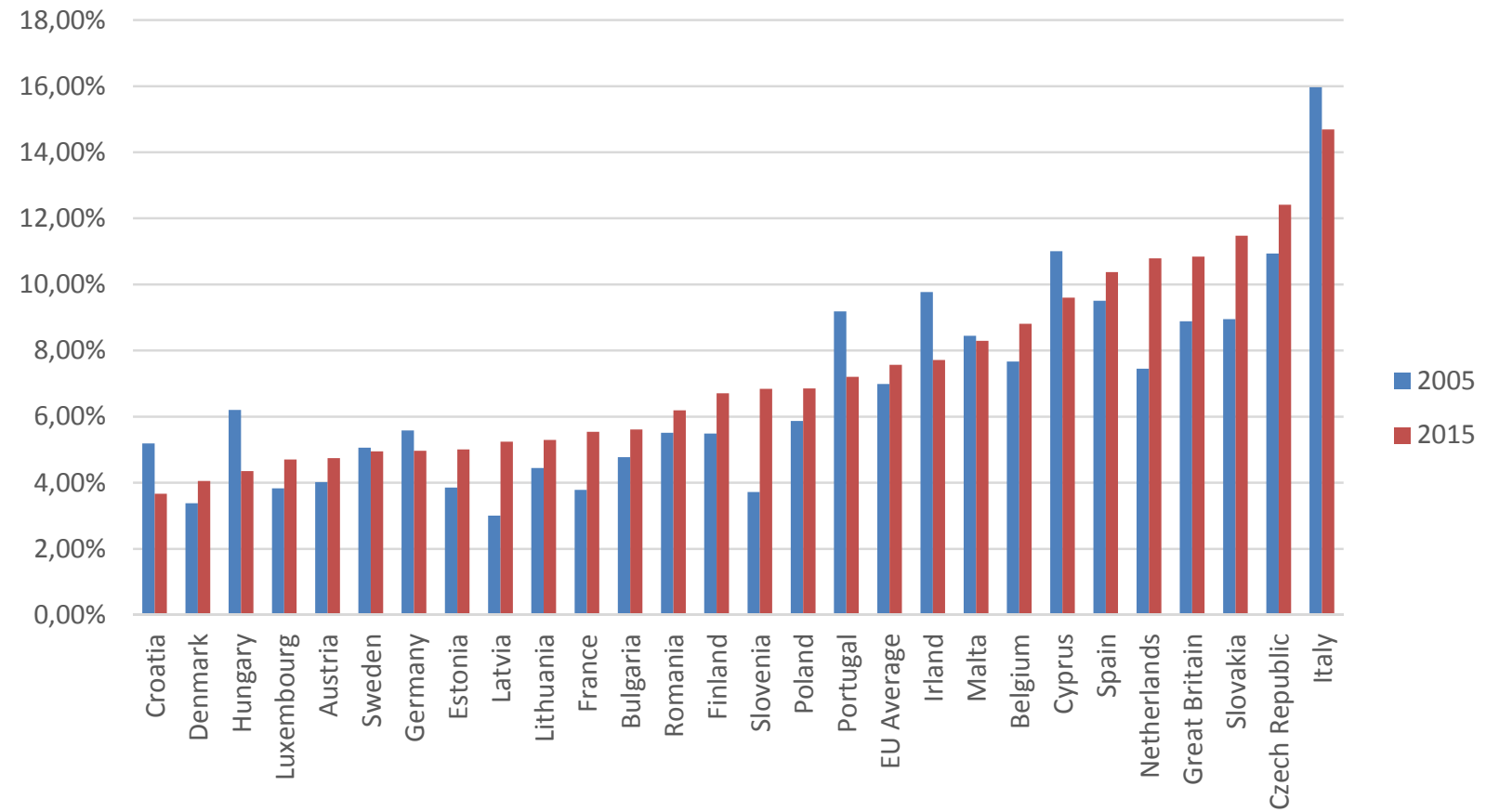

Source: EU-LFS, authors' calculations. 
Figure 7: Employed persons with a second job

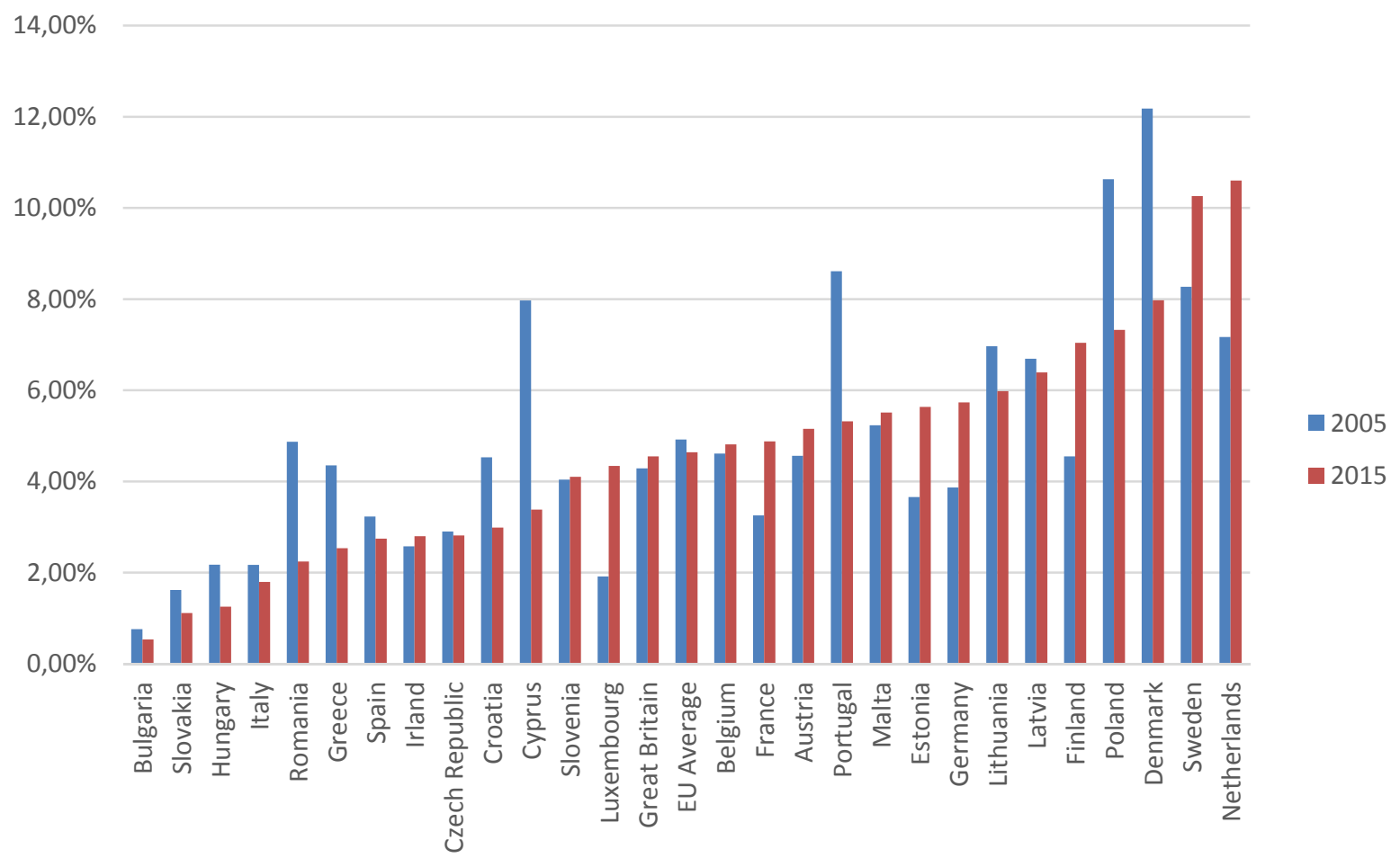

Source: EU-LFS, authors' calculations. 


\section{Appendix: Occupational classification according to ISCO-88}

1 Legislators, senior officials and managers

11 Legislators and senior officials

12 Corporate managers

13 Managers of small enterprises

\section{Professionals}

21 Physical, mathematical and engineering science professionals

22 Life science and health professionals

23 Teaching professionals

24 Other professionals

3 Technicians and associate professionals

31 Physical and engineering science associate professionals

32 Life science and health associate professionals

33 Teaching associate professionals (non-scientific)

34 Other associate professionals (medium skill level)

4 Clerks

41 Office clerks

42 Customer services clerks

5 Service and sales workers

51 Personal and protective services workers

52 Models, salespersons and demonstrators

6 Skilled agricultural, forestry and fishery workers

61 Skilled agricultural, forestry and fishery workers

62 Market-oriented skilled forestry, fishery and hunting workers (personal needs production)

7 Craft and related trades workers

71 Extraction and building trades workers

72 Metal, machinery and related trades workers

73 Precision, handicraft, craft printing and related trades workers

74 Other craft and related trades workers

8 Plant and machine operators and assemblers

81 Stationary plant and related operators

82 Machine operators and assemblers

83 Drivers and mobile plant operators

9 Elementary occupation

91 Sales and services elementary occupations

92 Agricultural, fishery and related laborers

93 laborers in mining, construction, manufacturing and transport

0 Armed forces occupations

01 Commissioned armed forces officers

Source: http://www.gesis.org/fileadmin/upload/dienstleistung/methoden/spezielle_dienste/inhaltsanalyse_berufsklass/isco88_1_.pdf (last accessed June 9, 2016) 